\title{
Chemistry, Taxonomy and Ecology of the potentially chimpanzee-dispersed Vepris teva sp.nov. (Rutaceae) of coastal thicket in the Congo Republic
}

\author{
Moses Langat ${ }^{1}$, Teva Kami ${ }^{2}$ \& Martin Cheek ${ }^{1}$
}

${ }^{1}$ Science Dept., Royal Botanic Gardens, Kew, Richmond, Surrey, TW9 3AE, United Kingdom

${ }^{2}$ Herbier National, Institut de Recherche National en Sciences Exactes et Naturelles (IRSEN), Cité Scientifique de Brazzaville, République du Congo

\begin{abstract}
.
Continuing a survey of the chemistry of species of the largely continental African genus Vepris, we investigate a species previously referred to as Vepris sp. 1 of Congo.

From the leaves of Vepris sp. 1 we report six compounds. The compounds were three furoquinoline alkaloids, kokusaginine (1), maculine (2), and flindersiamine (3), two acridone alkaloids, arborinine (4) and 1-hydroxy-3-methoxy-10-methylacridone (5), and the triterpenoid, $\beta$-amyrin (6).

Compounds 1-4 are commonly isolated from other Vepris species, compound $\mathbf{5}$ has been reported before once, from Malagasy Vepris pilosa, while this is the first report of ß-amyrin from Vepris. This combination of compounds has never before been reported from any species of Vepris. We test the hypothesis that Vepris sp.1 is new to science and formally describe it as Vepris teva, unique in the genus in that the trifoliolate leaves are subsessile, with the median petiolule far exceeding the petiole in length. Similar fleshy-leathery 4-locular syncarpous fruits are otherwise only known in the genus in Vepris glaberrima (formerly the monotypic genus Oriciopsis Engl.), a potential sister species, but requiring further investigation to confirm this phylogenetic position. We briefly characterise the unusual and poorly documented Atlantic coast equatorial ecosystem, where Vepris teva is restricted to evergreen thicket on white sand, unusual in a genus usually confine to evergreen forest. This endemic-rich ecosystem with a unique amphibian as well as plants, extends along the coastline from the mouth of the Congo River to southern Rio Muni, a distance of about $1000 \mathrm{~km}$, traversing five countries. We map and illustrate Vepris teva and assess its extinction risk as Endangered (EN B1ab(iii)+B2ab(iii)) using the IUCN standard. Only three locations are known, and threats include port and oil refinery construction and associated activities, with only one protected location, the Jane Goodall Institute's Tchimpounga Reserve. Initial evidence indicates that the seeds of Vepris teva are dispersed by chimpanzees, previously unreported in the genus
\end{abstract}

Key words. Alkaloids, Jane Goodall Foundation, Oriciopsis, TotalEnergies SA, triterpenoids, white sand habitat. 
bioRxiv preprint doi: https://doi.org/10.1101/2021.08.22.457282; this version posted August 22,2021 . The copyright holder for this preprint (which was not certified by peer review) is the author/funder, who has granted bioRxiv a license to display the preprint in perpetuity. It is made available under aCC-BY-NC-ND 4.0 International license.

\section{INTRODUCTION}

As part of a series of studies of the chemistry of Vepris led by the first author, material from a Congolese Vepris previously referred to in field studies as Vepris sp. 1 of Pointe Noire was investigated. In this paper we present the chemical results, compare the taxon morphologically within Vepris, test the hypothesis that this taxon is new to science and formally name it as Vepris teva Cheek. We also present data on its ecology in coastal thicket on white sand, a poorly known and highly threatened ecosystem on the equatorial Atlantic coast of Africa. Initial field observations suggest that the seeds of Vepris teva are dispersed by chimpanzees.

Vepris Comm. ex A. Juss. (Rutaceae-Toddalieae), is a genus with 93 accepted species, 23 in Madagascar and the Comores and 69 in Continental Africa with one species extending to Arabia and another endemic to India (Plants of the World Online, continuously updated). The genus was last revised for tropical Africa by Verdoorn (1926). Founded on the Flore du Cameroun account of Letouzey (1963a), eight new species were recently described from Cameroon (Onana \& Chevillotte 2015; Cheek et al., 2018a; Onana et al., 2019; Cheek \& Onana 2021), taking the total in Cameroon to 24 species, the highest number for any country globally. The greatest concentration of Vepris species in Cameroon is within the Cross-Sanaga Interval (Cheek et al., 2001) with 14 species of Vepris of which eight are endemic to the Interval. The Cross-Sanaga has the highest species and generic diversity per degree square in tropical Africa (Barthlott et al., 1996; Dagallier et al., 2020) including endemic genera such as Medusandra Brenan (Peridiscaceae, Breteler et al., 2015; Soltis et al., 2007). By comparison, neighbouring Gabon has just seven species of Vepris (Sosef et al., 2006) and just one species, Vepris lecomteana (Pierre) Cheek \& T. Heller is listed for CongoBrazzaville (Plants of the World Online, continuously updated), illustrating how under-recorded the Flora of this biodiverse country is. Several Cameroon species are threatened (Onana \& Cheek, 2011) and in one case considered globally extinct (Cheek et al., 2018a), although only two currently appear on the IUCN Red List: Vepris lecomteana (Pierre) Cheek \& T. Heller (Vulnerable, Cheek, 2004) and Vepris trifoliolata (Eng.) Mziray (Vulnerable, World Conservation Monitoring Centre, 1998). In other parts of Africa species are even more highly threatened, e.g., the Critically Endangered Vepris laurifolia (Hutch. \& Dalziel) O. Lachenaud \& Onana of Guinea-Ivory Coast (formerly V. felicis Breteler, Cheek 2017a; Lachenaud \& Onana, 2021).

In continental Africa, Vepris are easily recognised. They differ from all other Rutaceae because they have digitately (1-)3(-5)-foliolate (not pinnate) leaves, and unarmed (not spiny) stems. The genus consists of evergreen shrubs and trees, predominantly of tropical lowland evergreen forest, but with some species extending into submontane forests and some into drier forests and woodland. Vepris species are often indicators of good quality, relatively undisturbed evergreen forest since they are not pioneers. New species are steadily coming to light (Cheek et al., 2019).

Species of Vepris in Africa extend from South Africa, e.g. Vepris natalensis (Sond.) Mziray, to the Guinean woodland in the fringes of the Sahara Desert (Vepris heterophylla (Engl.) Letouzey). Mziray (1992) subsumed the genera Araliopsis Engl., Diphasia Pierre, Diphasiopsis Mendonça, Oricia Pierre, Oriciopsis Engl., Teclea Delile, and Toddaliopsis Engl. into Vepris, although several species were only formally transferred subsequently (e.g. Harris, 2000; Gereau, 2001; Cheek et al., 2009; Onana \& Chevillotte, 2015). Mziray's conclusions were largely confirmed by the molecular phylogenetic studies of Morton (2017) but Morton's sampling was limited, identifications appeared problematic (several species appear simultaneously in different parts of the phylogenetic trees) and more molecular work would be desirable. Morton studied about 14 taxa of Vepris, all from eastern Africa. More recently Appelhans \& Wen (2000) focussing on Rutaceae of Madagascar have found that the genus Ivodea Capuron is sister to Vepris and that a Malagasy Vepris is sister to those of Africa. However, the vast majority of the African species including all those of West and Congolian 
bioRxiv preprint doi: https://doi.org/10.1101/2021.08.22.457282; this version posted August 22,2021 . The copyright holder for this preprint (which was not certified by peer review) is the author/funder, who has granted bioRxiv a license to display the preprint in perpetuity. It is made available under aCC-BY-NC-ND 4.0 International license.

Africa, remain unsampled leaving the possibility open of changes to the topology of the phylogenetic tree when this is addressed.

Characteristics of some of the formerly recognised genera are useful today in grouping species. The "araliopsoid" species have hard, non-fleshy, subglobose, 4-locular fruit with 4 external grooves; the "oriciopsoid" soft, fleshy 4-locular syncarpous fruit; "oricioid" species are 4-locular and apocarpous in fruit; the fruits of "diphasioid" species are laterally compressed in one plane, bilocular and bilobed at the apex; while "tecleoid" species are unilocular in fruit and 1-seeded, lacking external lobes or grooves. There is limited support for these groupings in Morton's study,

Due to the essential oils distributed in their leaves, and the alkaloids and terpenoids distributed in their roots, bark and leaves, several species of Vepris have traditional medicinal value (Burkill, 1997). Burkill details the uses, essential oils and alkaloids known from five species in west Africa: Vepris hiernii Gereau (as Diphasia klaineana Pierre), Vepris suaveolens (Engl.) Mziray (as Teclea suaveolens Engl.), Vepris afzelii (Engl.) Mziray (as Teclea afzelii Engl.), Vepris heterophylla (Engl.) Letouzey (as Teclea sudanica A. Chev.) and Vepris verdoorniana (Exell \& Mendonça) Mziray (as Teclea verdoorniana Exell \& Mendonça) (Burkill, 1997: 651-653). Research into the characterisation and anti-microbial and anti-malarial applications of alkaloid and limonoid compounds in Vepris is active and ongoing (e.g., Atangana et al., 2017), although sometimes published under generic names no longer in current use, e.g. Wansi et al., (2008). Applications include as synergists for insecticides (Langat, 2011). Cheplogoi et al., (2008) and Imbenzi et al., (2014) respectively list 14 and 15 species of Vepris that have been studied for such compounds. A review of ethnomedicinal uses, phytochemistry, and pharmacology of the genus Vepris was recently published by Ombito et al., (2021), listing 213 different secondary compounds, mainly alkaloids and furo- and pyroquinolines, isolated from 32 species of the genus, although the identification of several of the species listed needs checking. However, few of these compounds have been screened for any of their potential applications. Recently, Langat et al., (2021) have published three new acridones and reported multi-layered synergistic anti-microbial activity from Vepris gossweileri (I.Verd.) Mziray, recently renamed as Vepris africana (Hook.f ex Benth.) Lachenaud \& Onana (Lachenaud \& Onana, 2021).

\section{MATERIALS \& METHODS}

\section{Chemistry}

Samples were made from live plants cultivated from seed at the Royal Botanic Gardens, Kew which were associated with the herbarium collections Mpandzou et al., 1754 (IEC, K) collected with the authorisation of Herbier National, Institut de Recherche National en Sciences Exactes et Naturelles (IRSEN), Cité Scientifique de Brazzaville

Spectroscopic and spectrometric analysis were conducted as follows: the FTIR spectra were recorded using a Perkin-Elmer Frontier/Spotlight 200 spectrometer. 1D and 2D NMR spectra were recorded in $\mathrm{CDCl}_{3}$ on a $400 \mathrm{MHz}$ Bruker AVANCE NMR instrument at room temperature. Chemical shifts $(\delta)$ are expressed in ppm and were referenced against the solvent resonances at $\delta_{\mathrm{H}} 7.26$ and $\delta_{\mathrm{C}} 77.23 \mathrm{ppm}$ for ${ }^{1} \mathrm{H}$ and ${ }^{13} \mathrm{C}$ NMR for $\mathrm{CDCl}_{3}$. Accurate masses were recorded on a Thermo Scientific Orbitrap Fusion spectrometer. Purity of compounds was monitored via thin layer chromatography (TLC) using pre-coated aluminium-backed plates (silica gel $60 \mathrm{~F}_{254}$, Merck) and compounds were visualised by $\mathrm{UV}$ radiation at $254 \mathrm{~nm}$ and then using an anisaldehyde spray reagent $\left(1 \% p\right.$-anisaldehyde: $2 \% \mathrm{H}_{2} \mathrm{SO}_{4}$ : $97 \%$ cold $\mathrm{MeOH})$ followed by heating. Final purifications used preparative thin layer chromatography (Merck 818133) and gravity column chromatography that was carried out using a 2 cm diameter column, which were packed with silica gel (Merck Art. 9385) in selected solvent systems. 
The leaves were freeze-dried and ground to fine powder using a blender. The dried leaves $(37 \mathrm{~g})$ were successively extracted using methylene chloride and methanol solvents to yield $1.7 \mathrm{~g}$ and $4.3 \mathrm{~g}$ respectively. The methylene chloride extract was subjected to gravity column chromatography packed with a 1:1 blend of silica gel merck 9385 and eluted isocratically using $10 \%$ ethyl acetate in methylene chloride, collecting $35 \mathrm{~mL}$. The fractions were monitored using TLC and fractions with the same retention times were pooled. Fractions 12-13 gave compound 5 which was determined to be 1-hydroxy-3-methoxy-10-methylacridone (Haensel \& Cybulksi, 1978). Fractions 14-18 gave compound 6 which was determined to be ß-amyrin (Okoye et al., 2014). Fractions 23-25 gave compound 2 which was determined to be maculine (Vaquette et al., 1976). Fractions 34-35 gave compound 4 which was determined to be arborinine (Haensel \& Cybulksi, 1978). Fractions 40-47 gave compound 3 which was determined to be flindersiamine (Vaquette et al., 1976) and fractions 55-63 gave compound 1 which was determined to be kokusaginine (Pusset et al., 1991) (Fig. 1).

\section{Figure 1: Furoquinoline and acridone alkaloids isolated from Vepris teva}<smiles>COc1cc2nc3occc3c(OC)c2cc1OC</smiles>

1<smiles>COc1cc2c(c(O)c1OC)c(=O)c1ccccc1n2C</smiles>

4<smiles>[R]c1c2c(cc3c(OC)c4ccoc4nc13)OCO2</smiles>

2: $\mathrm{R}=\mathrm{H}$

3: $\mathrm{R}=\mathrm{OCH}_{3}$<smiles>COc1cc(O)c2c(=O)c3ccccc3n(C)c2c1</smiles>

5

\section{Taxonomy}

The taxonomic study is based on herbarium specimens and observations of live material in CongoBrazzaville made by the second two authors in 2010-2012. All specimens cited have been seen. The methodology for the surveys in which the specimens were collected is given in Cheek \& Cable (1997). Herbarium citations follow Index Herbariorum (Thiers et al., continuously updated), nomenclature follows Turland et al., (2018) and binomial authorities follow IPNI (continuously updated). Material of the suspected new species was compared morphologically with material of all other species African Vepris, principally at K, but also using material and images from BM, EA, BR, FHO, G, GC, HNG, P and YA. Specimens at WAG were viewed on the Naturalis website (https://bioportal.naturalis.nl/). The main online herbarium used during the study apart from that of WAG was that of P (https://science.mnhn.fr/all/search ). Herbarium material was examined with a Leica Wild M8 dissecting binocular microscope fitted with an eyepiece graticule measuring in units of $0.025 \mathrm{~mm}$ at maximum magnification. The drawing was made with the same equipment using a Leica 308700 camera lucida attachment. 
bioRxiv preprint doi: https://doi.org/10.1101/2021.08.22.457282; this version posted August 22,2021 . The copyright holder for this preprint (which was not certified by peer review) is the author/funder, who has granted bioRxiv a license to display the preprint in perpetuity. It is made available under aCC-BY-NC-ND 4.0 International license.

\section{Extinction risk assessment}

Points were georeferenced using locality information from herbarium specimens. The map was made using simplemappr (Shorthouse, 2010). The conservation assessment was made using the categories and criteria of IUCN (2012), EOO was calculated with GeoCat (Bachman et al., 2011). Threats were observed by the second two authors directly in the field in Republic of Congo.

\section{RESULTS}

\section{Chemistry}

The structures of the alkaloids were determined based on comprehensive spectroscopic and spectrometric analysis, and the spectra of the known compounds were compared to those previously reported. The compounds were three furoquinoline alkaloids, kokusaginine (1) (Pusset et al., 1991), maculine (2) (Vaquette et al., 1976) and flindersiamine (3) (Vaquette et al., 1976), two acridone alkaloids, arborinine (4) (Haensel \& Cybulksi, 1978) and 1-hydroxy-3-methoxy-10-methylacridone (5) (Haensel \& Cybulksi, 1978), and one triterpenoid, B-amyrin (6) (Okoye et al., 2014). This combination of secondary compounds matches none of those reported from the 32 taxa of Vepris that have been chemically investigated to date (Ombito et al., 2021). While compounds 1-4 are relatively widespread in the investigated species, each having been recorded in 9-12 taxa, compound $\mathbf{5}$ is recorded only in one species, Vepris pilosa (Baker)I.Verd. (now a synonym of $V$. glomerata (F.Hoffm.)Engl.). However, compounds $\mathbf{2} \& \mathbf{3}$ have not been recorded in Vepris glomerata. Compound $\mathbf{6}$ has not been reported previously from Vepris. The chemical results therefore do not conflict with the morphologically-based conclusion that Vepris sp. 1 is new to science (see below).

\section{Morphology}

The morphological characteristics of Vepris sp. 1 are highly unusual within the genus. The subsessile leaves with the median petiolule far exceeding the petiolule in length is unique within the genus. The leathery-walled, syncarpous, 4-loculed, and slightly lobed, subverrucate fruits which have fleshy-juicy mesocarp surrounding the seeds are otherwise known in only one species, Vepris glaberrima, formerly segregated as the monotypic genus Oriciopsis. The two species share several unusual characters, such as numerous parallel, straight secondary and intersecondary nerves, with few quaternary nerves, sparse oil glands and long median petiolules, suggesting they are sister species. Vepris sp. 1 however differs greatly from the last species in the characters indicated below in table 1 and in the diagnosis below.

Table 1. Morphological characters separating Vepris teva from Vepris glaberrima

\begin{tabular}{|l|l|l|}
\hline Characters & Vepris teva & Vepris glaberrima \\
\hline Petiole length $(\mathrm{cm})$ & $0.14-0.4(-0.75)$ & $4-10$ \\
\hline Petiolule length $(\mathrm{cm})$ & $(0.3-) 0.5-1.1(-1.6)$ & $1.1-2.7$ \\
\hline $\begin{array}{l}\text { Median leaflet texture } \\
\text { and dimensions }(\mathrm{cm})\end{array}$ & $\begin{array}{l}\text { Coriaceous }(4.5-) 5.5-10.6(-14.3) \times \\
(2-) 2.7-3.5(-5.2)\end{array}$ & $\begin{array}{l}\text { Papyraceous } 7.5-18(-20) \mathrm{x} \\
2.5-8.3 \\
13-19(-20)\end{array}$ \\
\hline Acumen length $(\mathrm{mm})$ & $(3-) 4-9(-10)$ & Not visible \\
\hline $\begin{array}{l}\text { Oil gland dots on abaxial } \\
\text { surface }\end{array}$ & $\begin{array}{l}\text { Raised above surface, moderately } \\
\text { conspicuous }\end{array}$ & $4.8-5.1$ \\
\hline Petal length $(\mathrm{mm})$ & $3.3-3.5$ & Not developed \\
\hline Calyx lobe & Well-developed 0.4-0.7 mm long & Ovoid \\
\hline Fruit shape & Subglobose & $20-25 \times 16-20$ \\
\hline Fruit size $(\mathrm{mm})$ & $11-14 \times 11-13$ & \\
\hline
\end{tabular}


bioRxiv preprint doi: https://doi.org/10.1101/2021.08.22.457282; this version posted August 22,2021 . The copyright holder for this preprint (which was not certified by peer review) is the author/funder, who has granted bioRxiv a license to display the preprint in perpetuity. It is made available under aCC-BY-NC-ND 4.0 International license.

Vepris teva Cheek sp. nov. - Figs. 2 and 3.

Type. Republic of Congo, Kouilou, Port 8, along coast just northwest of Pointe Noire, near Pointe

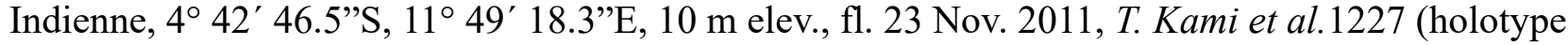
K000875074; isotypes EA, IEC, MO, P, US)

Syn. Vepris sp. 1 of Pointe Noire (Cheek et al., 2011).

Diagnosis: differs from all known trifoliolate species of Vepris in the median petiolule far exceeding the petiole in length (usually by a factor of 2-4 times) on reproductive stems, especially near the stem apex (vs. petiole exceeding petiolule in length in all other species). Most similar to Vepris glaberrima (Engl.) J.B.Hall ex D.J. Harris in the soft, leathery-fleshy, 4-loculed, and slightly lobed, subverrucate syncarpous fruit, differing in the inflorescences exceeding the petiole in length (vs. shorter than the petioles), the secondary nerves (10-)11-16(-18) on each side of the midrib (vs. 2030 ), the leaflet apices shortly rounded-acuminate (vs. long, acutely acuminate) and other characters shown in Table 1 above.

Dioecious (probably) shrub $0.5-1.5 \mathrm{~m}$ tall, moderately branched, glabrous apart from the bracteole margins. Stems terete, internodes (0-)0.9-5.3(-7.5) cm long, (1.5-)2-3.5(-4) mm diam. at lowest leafy node, epidermis glossy, medium brown, finely longitudinally striate, at length splitting longitudinally, soon lenticellate, lenticels very sparse white, orbicular or elliptic, often longitudinally divided in two, $(0.3-) 0.5-1.3(-2.25) \times(0.2-) 0.3-0.6(-0.9) \mathrm{mm}$.

Leaves alternate, trifoliolate (rarely unifoliolate), median leaflet usually slightly longer than lateral leaflets, elliptic, less usually obovate-elliptic, (4.5-)5.5-10.6(-14.3) x (2-)2.7-3.5(-5.2) cm, acumen broadly triangular $(0.3-) 0.4-0.9(-1) \times 0.25-0.45 \mathrm{~cm}$, apex rounded, base acute-decurrent, secondary nerves $(10-) 11-16(-18)$ on each side of the midrib, arising at $50-80^{\circ}$ from the midrib, straight, united by a slightly looping inframarginal vein $0.6-1.2 \mathrm{~mm}$ from the margin (Fig. 1A-C), tertiary nerves conspicuous on the abaxial but not adaxial surface, mainly parallel to the secondary nerves, uniting transversely only in the outer part of the blade (Fig. 1B), quaternary nerves inconspicuous; oil gland dots translucent in transmitted light, inconspicuous on the adaxial surface, conspicuous but concolorous, raised on the abaxial surface (Fig. 1B \& C), (2-)4-7(-8) per $\mathrm{mm}^{2}$, the diameter of the glands $0.1-0.225 \mathrm{~mm}$; lateral leaflets as the median leaflet, but (4.7-)5.5-8.7)-12.7) $\mathrm{x}(1.9-) 2.2-3.4(-4.25) \mathrm{cm}$, base acute. Petiolules canaliculate, those of fertile stems exceeding the petiole in length (Fig. $1 \mathrm{~A} \& \mathrm{C}),(0.3-) 0.5-1.1(-1.6) \mathrm{cm}$ long, those of median leaflets much longer than the lateral; articulated at junction with the petiole. Petiole canaliculate, those of fertile stems 0.15-0.4(-0.75) cm long, those of sterile stems (e.g. Mpandzou 1653, IEC, K) much longer, 4-5.2 cm long.

Inflorescences terminal, less usually axillary in the most distal subapical node(s), thyrsoid, contracted, about as wide as long $0.4-0.85 \mathrm{~cm}$ diam., 5-20-flowered, main axis with 1-3 pairs of 13 -flowered cymes \pm evenly spaced from the base; bracts quadrate-triangular, $0.5 \times 0.8 \mathrm{~mm}$.

Pedicels each subtended by a second order bract and two bracteoles, all ovate-triangular, $0.5-0.6 \mathrm{x}$ $0.3 \mathrm{~mm}$, margins sparingly minutely simple hairy. Female flowers_unknown, apart from parts persisting in fruit. Stigma discoid, peltate, subsessile, $1 \mathrm{~mm}$ diam. Male flowers with pedicel 1.2$1.5 \times 0.5 \mathrm{~mm}$, terete, widening to $0.8-1.2 \mathrm{~mm}$ wide below the sepals, lacking conspicuous glands. Calyx with sepals 4, imbricate, erect, broader than long, transversely semi-elliptic, 0.4-0.7(-0.9) x 1.1-1.6 mm, apex broadly rounded or rounded-obtuse._Petals 4, oblanceolate, concave, erect, 3.2$3.5 \times 1.4-1.5 \mathrm{~mm}$, apex obtuse, rounded or minutely retuse, margin membranous, central part thickened with numerous raised oil-glands conspicuous on the abaxial surface._Stamens 8, erect, free, slightly exceeding petals, subequal, the outer 4 with slightly longer filaments than the inner 4 , 
bioRxiv preprint doi: https://doi.org/10.1101/2021.08 22 457282; this version posted August 22, 2021. The copyright holder for this preprint

(which was not certified by peer review) is the author/funder, who has granted bioRxiv a license to display the preprint in perpetuity. It is made available under aCC-BY-NC-ND 4.0 International license.

Figure 1: Vepris teva. (A) Habit, fruiting stem; (B) detail of leaflet blade showing oil gland dots and nervation, lower surface of blade in foreground; (C) detail of male inflorescence; (D) male flower, side view; (E) as D, two petals removed to show stamens; (F) pistil of male flower, 4-lobed, viewed from above; $(\mathrm{G})$ male flower, 2 petals and 3 stamens removed to show pistil; $(\mathrm{H})$ mature fruit, side view (seed on right); (I) fruit, plan view; (J) fruit, transverse section, showing four locules, three aborted and one with seed. A \& H-J from Mpandzou et al., 1198, B \& G from Kami, T. et al 1356; C-F from Kami, T. et al., 1227. Drawn by Juliet Williamson.

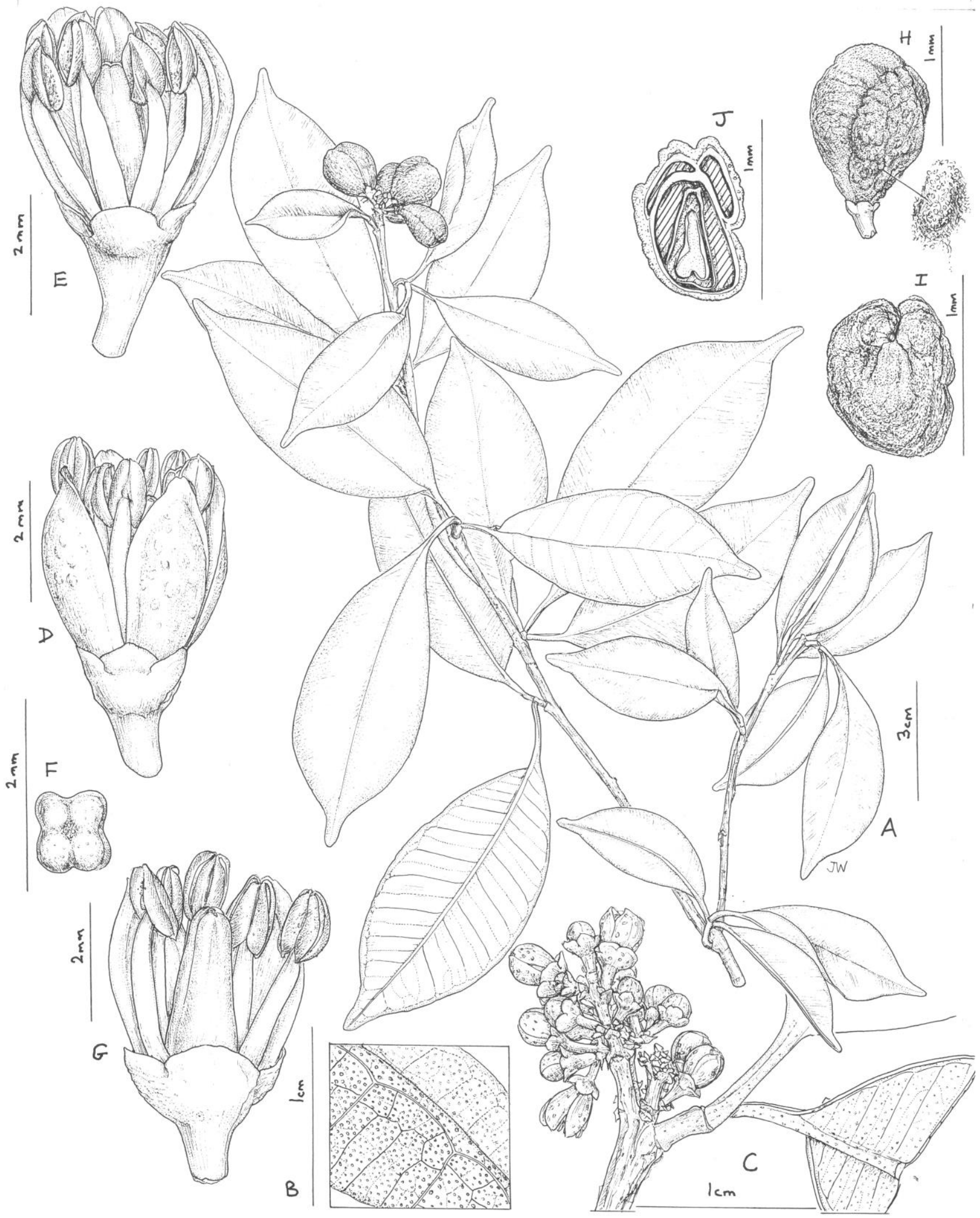


bioRxiv preprint doi: https://doi org/10.1101/2021 08 22 457282; this version posted August 22, 2021. The copyright holder for this preprint (which was not certified by peer review) is the author/funder, who has granted bioRxiv a license to display the preprint in perpetuity. It is made available under aCC-BY-NC-ND 4.0 International license.

Figure 3. Vepris teva. Shrub with mature (yellow) and immature (green) fruits. Note the sessile leaves. From Mpandzou et al., 1198 (IEC, K). Photo by M. Cheek.

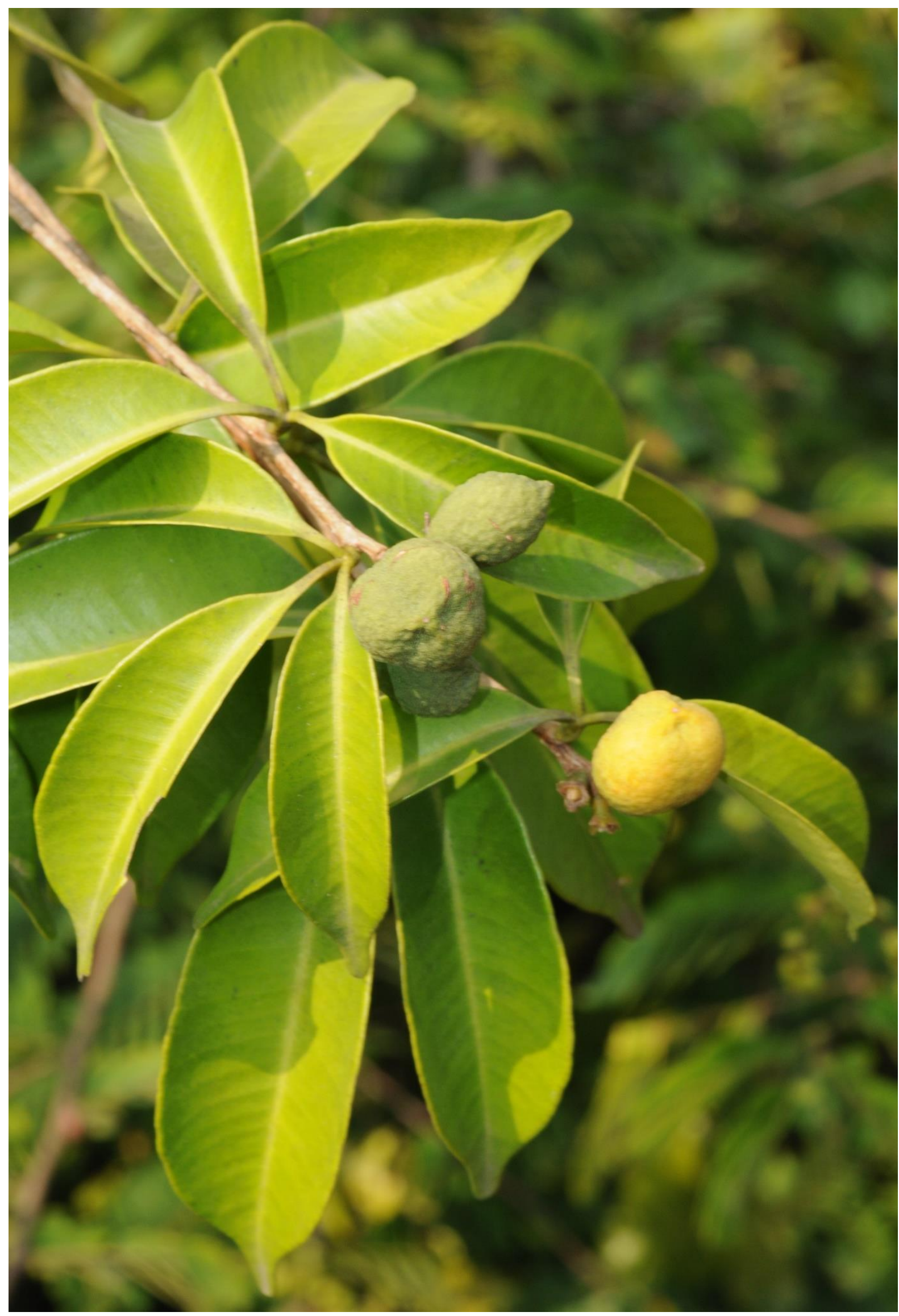


filaments terete, $2.5-3.0 \mathrm{~mm}$ long, $0.4 \mathrm{~mm}$ wide at base, narrowing gradually to $0.2 \mathrm{~mm}$ wide at apex; anthers submedifixed, introrse to lateral dehiscence, oblong-ovate, $1-1.2 \times 0.6 \mathrm{~mm}$; disc inconspicuous; ovary (pistillode) obclavate-4-angled/fluted, 3-3.1 x 1.2-1.3 mm, $0.7 \mathrm{~mm}$ wide at apex, apex rounded with a slight central depression, in plan view 4-lobed (Fig. 1F) stigmas punctate, minute; 4-locules each biovulate. Fruit in terminal clusters of (1-)2-4, yellow-orange, subglobose or obovoid, apex rounded-slightly depressed, longitudinally 4-grooved to slightly lobed, 11-14 x 11-13 mm, 4-locular but usually with 1-2 locules incompletely formed, 1-2(-4)-seeded by abortion. Pericarp leathery, surface minutely wrinkled to slightly verrucate (Fig.5), 0.5-0.7 mm thick, endocarp bony $0.05 \mathrm{~mm}$ thick; mesocarp liquid, sweet to the taste._Seed encased in a cartilaginous, vascular endocarp, ellipsoid, 4-4.5 x 2.4 x 1.8-2 mm (Fig. 1H, Fig. 5).

Distribution. Republic of Congo, Kouilou Department, Tchimpounga to Djeno. Fig. 4

Figure 4. Vepris teva Global distribution

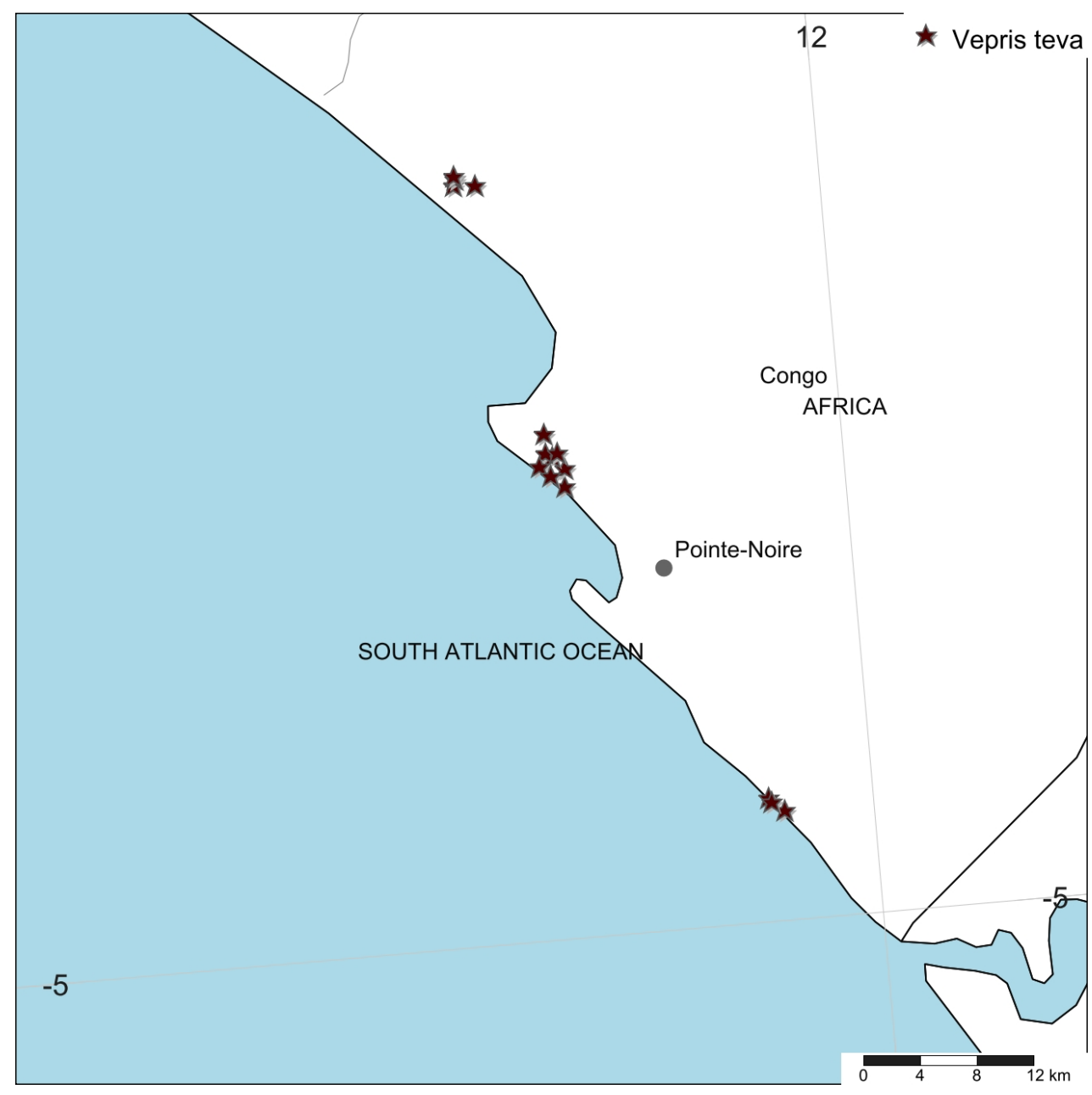

Ecology. The evergreen thicket ecosystem on white sand on the Atlantic coast of Africa Vepris teva is restricted to the key vegetation type, thicket on white sand, that occurs in a coastal ecosystem extending along the equatorial Atlantic coast of Africa in the southern hemisphere. This 
bioRxiv preprint doi: https://doi.org/10.1101/2021.08.22.457282; this version posted August 22,2021 . The copyright holder for this preprint (which was not certified by peer review) is the author/funder, who has granted bioRxiv a license to display the preprint in perpetuity. It is made available under aCC-BY-NC-ND 4.0 International license.

ecosystem extends from the mouth of the Congo River in the Democratic Republic of Congo, along the coast through Angolan Cabinda, Republic of Congo into southern Gabon, with some areas thought to extend into Rio Muni of Equatorial Guinea. It extends discontinuously along the coastline for about $1000 \mathrm{~km}$ and extends inland for between $100-3000 \mathrm{~m}$, and is based on old, partly dissected and flattened, highly leached white sand dunes that run parallel to the coast, alternating with lower, wet or seasonally wet drainage areas often developing black peaty soils, that can develop either swamp forest e.g. with Alstonia congensis Engl. trees and an understorey of Acrostichum aureum L. or a wetland grassland community including Cyperaceae, Utricularia, Drosera, Xyridaceae and Stipularia africana P.Beauv. Thicket develops on the top of the ridges. In the ecotone transition areas, the shallow slopes between the thicket and wetland area, a sparse grassland develops on the upper part of the white sand with Chlorophytum, Dissotis congolensis (Cogn. ex Büttner) Jacq.-Fél., Eulophia caricifolia (Rchb.f.) Summerh., and in the lower damper, seasonally inundated parts of the ecotone, grass species including Anadelphia hamata Stapf, and herbs such as Neurotheca corymbosa Hua, both globally restricted to this vegetation type.

On the seaward side of the dunes a sea-shore community including halophytes develops with succulent species such as Sansevieria longiflora Sims, while in brackish inlets the Atlantic mangrove community is formed, including Rhizophora racemosa G.Mey. On the landward side of the ecosystem two substrates interface with the white sand, red-brown loam, and grey sand which each have their own communities of grassland species. This ecosystem has rarely been referred to in the literature. The best account is probably that by Vande Weghe (2007) regarding the areas in southern Gabon. He refers to a sand-burrowing toad Hemisus perretii Laurent (Vande Weghe, 2007: 250) that is restricted to this ecosystem. Van der Burgt \& Merklinger (2012) have characterised this ecosystem in the Republic of Congo after our studies in 2010-2012, recognising the nine habitats referred to above, six of which have threatened, or provisionally threatened plant species often restricted to this ecosystem. However, Critically Endangered (CR) and Endangered (EN) species are reported only from two of the habitats: the thicket (13 species) and sparse grassland on white sand habitats ( 2 species). The evergreen thicket which is the habitat to which Vepris teva is restricted is only 2-3 m tall and consists of shrubs, intermixed with very few emergent tree species e.g. Hyphaene guineensis Schumach. \& Thonn. and Tessmannia dawei J.Léonard, numerous climbers and several herbs, characteristically:

Common shrubs: Chrysobalanus icaco subsp. icaco L., Syzygium guineense var. guineense (Willd.) D C., Ochna multiflora DC, Dalbergia grandibracteata De Wild., Manilkara lacera (Baker) Dubard, Premna serratifolia L., Rytigynia dewevrei Robyns, Trichoscypha imbricata Engl., Tricalysia coriacea (Benth.) Hiern, Vismia affinis Oliv., Psychotria kimuenzae De Wild., Psydrax moandensis Bridson, Thomandersia butayei De Wild., Baphia leptostemma subsp. leptostemma Baill. and Leptactina mannii Hook.f.,

Common climbers: Pentarhopalopilia marquesii (Engl.) Hiepko, Uvaria versicolor Pierre ex Engl. \& Diels, Calycobolus cabrae (De Wild. \& T.Durand) Heine, Jasminum kwangense Liben and Ancylobothrys scandens (Schumach. \& Thonn.) Pichon

Common herbs: Pseuderanthemum lindavianum De Wild. \& T. Durand, Coleus calaminthoides Baker and Dracaena braunii Engl.

The grassland is maintained by dry season fires which kill most or all woody plants (Vande Weghe, 2007), none of which, curiously, appear fire-adapted. Such grassland fires were recorded by us in Congo in July 2010. Owing to the sparsity of the herbs in the grassland, fires are not intense due to the low fuel- load. It is sometimes possible for shrubs to establish in grassland. Chrysobalanus icaco is a shrub which, once established, in the absence of fire, can spread laterally to form a thicket 
bioRxiv preprint doi: https://doi.org/10.1101/2021.08.22.457282; this version posted August 22,2021 . The copyright holder for this preprint (which was not certified by peer review) is the author/funder, who has granted bioRxiv a license to display the preprint in perpetuity. It is made available under aCC-BY-NC-ND 4.0 International license.

in which other species of shrub and tree can colonise, leading towards succession from grassland to thicket.

Among the endemic and highly threatened shrub species of this ecosystem, several apart from Vepris teva, were found to be new to science. Of these, those recently published are Dracaena marina Damen (Damen et al., 2018), Baphia vili Cheek (Cheek et al., 2014), Salacia arenicola Gosline (Gosline et al., 2014). However, several additional species remain to be published.

\section{Local names and uses. None are recorded.}

Etymology. Named for Teva Kami, lead collector of the type specimen, who played a key role in the discovery of this species and further research upon it concerning interactions with chimpanzees (see below).

Conservation. Vepris teva is known from nine specimens and seven sight-records made between July 2011-Feb. 2012. These equate to an area of occupation of $40 \mathrm{~km}^{2}$ using the IUCN-preferred 4 $\mathrm{km}^{2}$ gridcells, and an extent of occurrence of $172 \mathrm{~km}^{2}$. It is restricted to coastal thicket on white sand habitat in Republic of Congo. This habitat is thought to extend along the Atlantic coast from coastal DRC to southern Equatorial Guinea. Despite targetted surveys in this habitat through most of this range especially in Congo, Vepris teva has only been found at three of the more than eight locations studied. These are: 1) Pointe Noire at Point Indienne; 2) Djeno; 3) Tchimpounga. At the first location, the plants are threatened by an extension northward of the port of Pointe Noire to accommodate export of rock phosphate, manganese, iron-ore for which there is currently insufficient port capacity. Plants of Vepris teva are also threatened by cutting of their coastal thicket habitat for charcoal and for clearance for housing. At the second location, plants are threatened by the infrastructure and activities of the Total E\&P Congo petro-chemical plant (part of TotalEnergie S.A.), the installation of which appears to have destroyed much of the habitat of Vepris teva at this location. Indirectly, Total, as the major employer at Djeno attracting labour which requires local accommodation, appears to have stimulated an expansion of urbanisation, resulting in Vepris teva habitat being parcelled for sale as house building plots (Cheek pers. obs. 2012). At Tchimpounga, a reserve created by the Jane Goodall Foundation to protect chimpanzees, Vepris teva uniquely appears protected and secure so long as this venture is supported. In view of the EOO and AOO, and the threats stated, we here assess Vepris teva as Endangered (EN B1ab(iii)+B2ab(iii)).

\section{Additional specimens and observations}

Republic of Congo, Dept. Kouilou, Tchimpounga, along coast NW of Pointe Noire, about $7 \mathrm{~km}$ SE of the Kouilou River Bridge, in the Tchimpounga Chimpanzee Sanctuary, fl. 3 Dec. 2011, T. Kami et al., 1356 (IEC, K000875073); Tchimpounga pointe 2 zone ex gorillon, fl. 5 Nov. 2012, Mpandzou et al., 1641 (IEC, K000875078); Tchimpounga, bas-Kouilou, Bois de Singe, st. 6 Dec. 2012; Mpandzou et al.,1754 (IEC, K000875081); Tchimpounga, Point 1 zone de soleil, fl. 2 Nov. 2012, T. Kami et al., 1421 (BR, IEC, K000875083); Tchimpounga, Point 1 zone de soleil, fl. 3 Nov. 2012, T. Kami 1437 et al., (IEC, K000875082); Pointe Noire, Port 8, along coast just northwest of Pointe Noire, near Pointe Indienne, 4 42' 46.5’'S, 1149 18.3E, 10 m elev., fl. 23 Nov. 2011, T. Kami et al., 1227 (holotype K000875074; isotypes EA, IEC, MO, P, US); Pointe Noire, fr. 9 July 2011, Mpandzou et al., 1198 (IEC, K000875072, P); near Pointe Indienne, 24 Nov. 2011, Port Observations 36; ibid. 24 Nov. 2011, Port Observations 61; ibid, 25 Nov. 2011, Port Observations 91; ibid. 26 Nov. 2011, Port Observations 128; 27 Nov. 2011, Port Observations 215; Djeno a côté de Terminal de Djeno, fr. 6 Dec. 2012, Mpandzou et al., 1768 (IEC, K000875077); ibid., fr. 6 Dec. 2012, Mpandzou et al., 1754 (IEC, K000875081); Djeno, near Total refinery, 15 Feb. 2012, Port Observations 309; ibid., 13 July 2011, Port Observations 303. 
bioRxiv preprint doi: https://doi.org/10.1101/2021.08.22.457282; this version posted August 22,2021 . The copyright holder for this preprint (which was not certified by peer review) is the author/funder, who has granted bioRxiv a license to display the preprint in perpetuity. It is made available under aCC-BY-NC-ND 4.0 International license.

Notes. We first detected Vepris teva in July 2011, during the dry season environmental impact studies for a proposed new port facility near the major existing port of Pointe Noire, Congo's principal port and commercial centre. It was provisionally named as 'Vepris sp. 1 of Pointe Noire,' and considered likely to be new to science since it matched no other known species of the genus in tropical Africa (Cheek et al., 2011). Further collections were made in a wet season survey in Nov. and Dec. 2011. These surveys resulted in the discovery of many other rare species, usually previously unknown to science, mainly confined to evergreen thicket on coastal white sand. Consequently, surveys in Nov.-Dec. 2012 were made along the length of the Congolese coastline to map the full national extent of this ecosystem and of its rare and threatened species. It was discovered that unlike many of the coastal thicket species, Vepris teva is restricted to only a small length of the coast, from Djeno in the south to Tchimpounga in the north. At these three sites, wherever coastal thicket on white sand appears, Vepris teva can be fairly frequent. However, when thicket become degraded or damaged, it is no longer present. Vepris teva sometimes grows alongside another species of the genus, Vepris africana (formerly Vepris gossweileri). The second species extends into Angola and to S.Tomé (Lachenaud \& Onana, 2021). The two species cannot be confused since the first is trifoliolate, while the second is unifoliolate. No Vepris species other than these two have been found in coastal thicket on white sand in Congo.

Our knowledge of the phenology of Vepris teva is restricted to two periods of the year - July (dry season) and Nov.-Dec. (wet season). At both seasons plants were found in both flower and fruit. All flowers collected are monomorphic and have well-developed stamens with pollen, and are therefore supposed to be male. This is supported by our observation that while the fruits (the undoubted products of female flowers) have a $1 \mathrm{~mm}$ diam. peltate, discoid stigma, peltate stigmas have not been in any of the flowers which are therefore male. Since Vepris species have been found to be dioecious wherever their reproductive strategies have been studied, we conclude that female flowers remain to be discovered, although female plants (in fruit) have been collected. There is a small possibility that Vepris teva, atypically in the genus, might have hermaphroditic flowers.

Vepris teva grows very slowly from seed. Three plants cultivated at the Royal Botanic Gardens, Kew from seed collected in 2011, reached only 15-25 cm tall after five years. By March 2020, after 8.5 years, the plants had reached $30-45 \mathrm{~cm}$ tall, but none had shown signs of flowering. All three of these plants showed the long petiole of sterile plants, and not the characteristic extremely short petioles of reproductive individuals. Thus, the age of sexual maturity is likely to be at least 10 years in Vepris teva.

Because Vepris teva has a 4-locular syncarpous flower producing a soft fleshy fruit it would formerly have been classified in the monotypic genus Oriciopsis, together with $V$. glaberrima (Letouzey, 1963b: 79-80). The last species occurs in lowland evergreen forest at the junction of Cameroon, C.A.R. and Gabon and is also a small, sparingly branched shrub. It is conceivable that the two are sister species (see above). Four-locular syncarpous ovaries are also seen in the formerly accepted genera Araliopsis and Toddaliopsis, but in these taxa the fruits are hard. The former occurs in W-C Africa but is a large tree with digitately 5-foliolate leaves, the second a tree of coastal E Africa with a subspiny, "nut-like" fruit.

Vepris teva appears unique and is easily recognisable in the genus and in its habitat because of the combination of long petiolules with extremely short petioles on the fertile stems. The petioles can be so contracted that they are almost invisible, and it then appears that there are three simple, leaves, each on its own petiole (in fact leaflets on petiolules) at each node. 
bioRxiv preprint doi: https://doi.org/10.1101/2021.08.22.457282; this version posted August 22, 2021. The copyright holder for this preprint (which was not certified by peer review) is the author/funder, who has granted bioRxiv a license to display the preprint in perpetuity. It is made available under aCC-BY-NC-ND 4.0 International license.

\section{Chimpanzee-mediated seed dispersal.}

During field surveys of the vegetation in which Vepris teva occurs, the last author tested the hypothesis that the fruits might conform to the 'spat seed' syndrome characteristic of some primatedispersed plant species (Sengupta et al., 2015; Dominy \& Duncan, 2005). When the base of a fruit plucked from a shrub is sucked, the pleasantly sweet, watery mesocarp with the seed(s) enters the mouth, the juice can be swallowed, and the slippery seed(s) in their endocarp(s) spat out (Fig. 5).

Figure 5. Vepris teva. The empty, leathery pericarp after juice abstraction and three spat seeds.

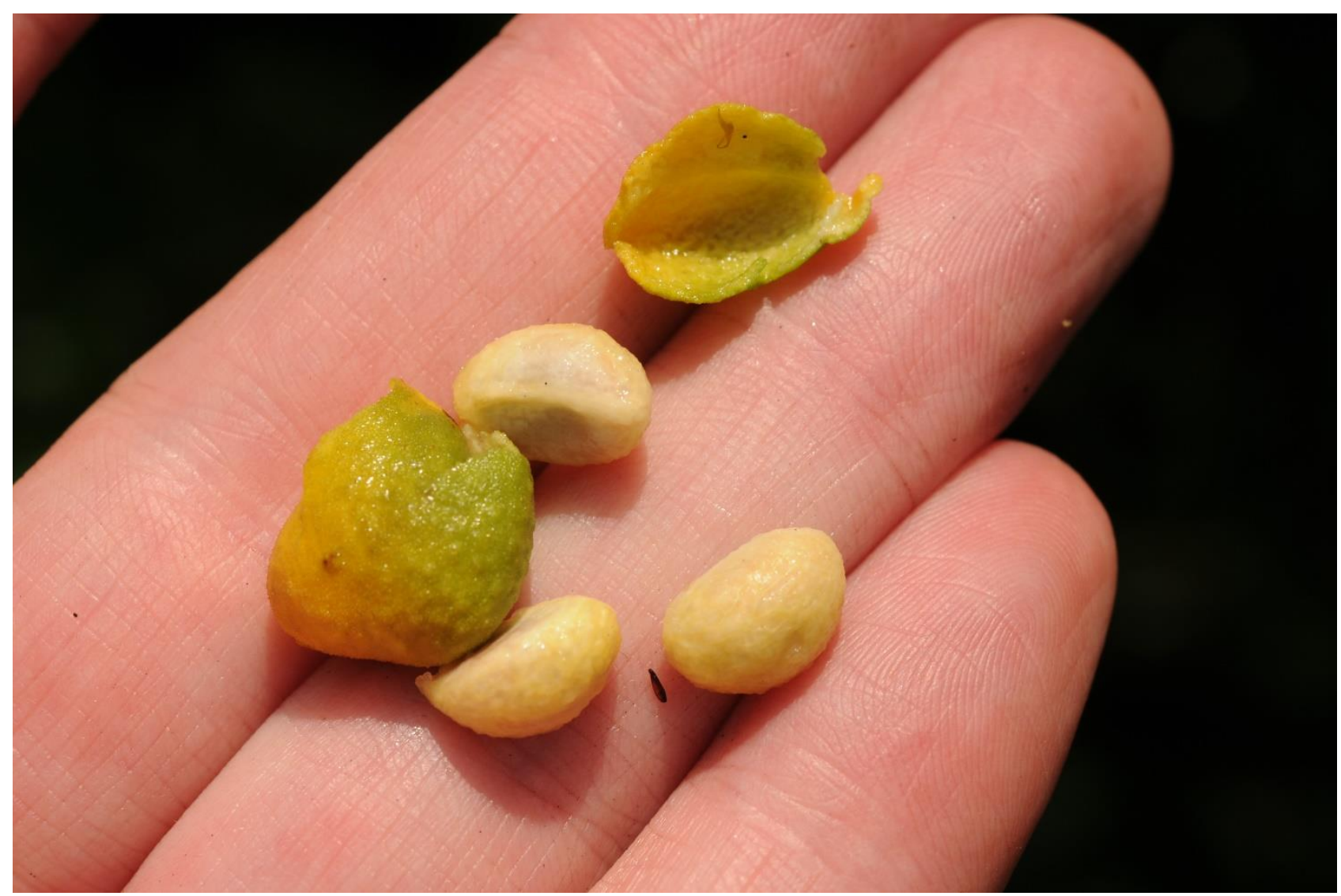

One of the three known locations for Vepris teva is the Tchimpounga Reserve, co-managed by the Jane Goodall Institute (Jane Goodall Institute, 2018) which focuses on chimpanzee conservation and research of both rescued animals from captivity and hunting, and chimpanzees indigenous to the coastal thicket ecosystem (see below). During field observations for doctoral studies of fruit consumption by chimpanzees from tree species by the second author (2014-2020, Kami, 2021), chimpanzees were observed to seemingly feed on the fruits of this species of Vepris - evidenced by empty pericarps and separated, spat seeds of this species after they had been in the vicinity of the fruiting shrubs. Chimpanzee seed dispersal of Vepris teva seems very likely but more detailed studies are needed to confirm this.

\section{CONCLUSIONS}

The case of Vepris teva illustrates the importance of uncovering and publishing species before they become extinct and become lost forever, together with their potential applications for humanity, in this case secondary compounds with potential e.g., as anti-microbials, natural insecticides and in the case of $ß$-amyrin, recorded here for the first time in Vepris, strong anti-inflammatory (Okoye et al., 
bioRxiv preprint doi: https://doi.org/10.1101/2021.08.22.457282; this version posted August 22,2021 . The copyright holder for this preprint (which was not certified by peer review) is the author/funder, who has granted bioRxiv a license to display the preprint in perpetuity. It is made available under aCC-BY-NC-ND 4.0 International license.

2014). For each of the last 15 years or more, about 2000 new species of flowering plant have been published by scientists each year (Cheek et al., 2020), adding to the estimated 369000 already documented (Nic Lughadha et al., 2016). However, only 7.2\% of species have been assessed for their threat status and are included on the Red List using the IUCN (2012) standard (Bachman et al., 2019). Newly discovered species, such as Vepris teva, reported in this paper, are likely to be threatened, since widespread species tend to have been already discovered. There are notable exceptions to this rule (e.g., Vepris occidentalis Cheek (Cheek et al., 2019) a species widespread in West Africa from Guinea to Ghana). However, it is generally the more range-restricted, infrequent species that remain unknown to science. This makes it urgent to find, document and protect such species before they become extinct. Until species are described and known to science, it is difficult to assess them for their IUCN conservation status and so the possibility of protecting them is reduced (Cheek et al., 2020). Documented extinctions of plant species are increasing, e.g., in coastal forest of Cameroon, Oxygyne triandra Schltr. is considered extinct at its sole locality, the forest at Mabeta-Moliwe in the foothills of Mt Cameroon (Cheek et al., 2018b; Cheek \& Williams 1999; Cheek, 1992), Inversodicraea bosii (C.Cusset) Rutish. \& Thiv. at the Lobe Falls (Cheek et al., 2017) and in Gabon Pseudohydrosme buettneri Engl. (Cheek et al., 2021) in coastal forest. There are also examples of species that appear to have become extinct even before they are known to science, such as in Cameroon Vepris bali Cheek (Cheek et al., 2018a), and in Gabon Pseudohydrosme bogneri (Moxon-Holt \& Cheek, 2021). Human pressures have been the cause of these extinctions in all these cases

In the Republic of Congo natural habitat is fortunately relatively extensive and intact, but in some specialised ecosystems such as that with the evergreen thicket on white sand habitat described above, to which Vepris teva is restricted, large areas have entirely disappeared and others are set to follow them.

Further effort in prioritising high priority areas for plant conservation as Tropical Important Plant Areas (TIPAs), using the revised IPA criteria set out in Darbyshire et al., (2017)) is being implemented in Guinea (Couch et al., 2019). TIPAs are also in progress in countries such as Cameroon, Ethiopia, Mozambique and Uganda and might be extended elsewhere in Africa such as to the Republic of Congo, to reduce the risk of future global extinctions of range-restricted endemic species such as Vepris teva.

\section{ACKNOWLEDGEMENTS}

The authors thank Dr Emile Kami, former Head of the National Herbarium of Republic of Congo (IEC) for expediting authorisation for botanical prospection and export of material to RBG, Kew. Aydrif Laurel Mpandzou, Emile Kami, Augustin Ngoliélé, Gilbert Nsongola, Xander van der Burgt Helen Pickering, Mme Yvette Bongou \& Felix Merklinger assisted collecting the material in Congo. Paul Reed, John Merry and Colin Harris of MPD Congo S.A. provided logistic support. At the Jane Goodall Institute's Tchimpounga Reserve, Dr Rebeca Atiencia is thanked for facilitating access for our surveys. Sarah Redstone and colleagues in the Quarantine House RBG, Kew are thanked for initially growing Vepris teva from seed, and especially Bradley Gangadeen of the Science Glass for growing it on. The import and safe use of this wild collected plant material was enabled through the use of Defra Plant Health Licence 2149/194627/5.

\section{APPENDIX}

NMR spectroscopic data for the compounds isolated from Vepris teva are provided as supplementary information. 


\section{REFERENCES}

Appelhans MS, Wen J. 2020. Phylogenetic placement of Ivodea and biogeographic affinities of Malagasy Rutaceae. Plant Systematics and Evolution 306:1-14.

Atangana AF, Toze FAA, Langat MK, Happi EN, Mbaze LLM, Mulholland DA, Wansi JD. 2017. Acridone alkaloids from Vepris verdoorniana (Excell \& Mendonça) Mziray (Rutaceae). Phytochemistry Letters 19:191-195.

Bachman SP, Field R, Reader T, Raimondo D, Donaldson J, Schatz GE, Lughadha EN. 2019. Progress, challenges and opportunities for Red Listing. Biological Conservation 234:45-55. https://doi.org/10.1016/j.biocon.2019.03.002

Bachman S, Moat J, Hill AW, de la Torre J, Scott B. 2011. Supporting Red List threat assessments with GeoCAT: geospatial conservation assessment tool, in: Smith V, Penev, eds. eInfrastructures for data publishing in biodiversity science. ZooKeys 150:117-126. Available from: http://geocat.kew.org/ [accessed 19 July 2020].

Barthlott W, Lauer W, Placke A. 1996. Global distribution of species diversity in vascular plants: towards a world map of phytodiversity. Erdkunde 50:317 327 https://doi.org/10.1007/s004250050096

Breteler FJ, Bakker FT, Jongkind CC. 2015. A synopsis of Soyauxia (Peridiscaceae, formerly Medusandraceae) with a new species from Liberia. Plant Ecology and Evolution. 148(3):409-419. https://doi.org/10.5091/plecevo.2015.1040

Burkill HM. 1997. The Useful Plants of West Tropical Africa. Vol. 4, families M-R. Royal Botanic Gardens, Kew.

Cheek M. 1992. A Botanical Inventory of the Mabeta-Moliwe Forest. Royal Botanic Gardens, Kew

Cheek M. 2004. Vepris lecomteana. The IUCN Red List of Threatened Species 2004:

e.T46174A11039677. https://dx.doi.org/10.2305/IUCN.UK.2004.RLTS.T46174A11039677.en. (Do wnloaded on 22 May 2021).

Cheek M. 2017. Vepris felicis. The IUCN Red List of Threatened Species 2017:

e.T65064584A65064590. http://dx.doi.org/10.2305/IUCN.UK.2017-

3.RLTS.T65064584A65064590.en. (accessed: 05/2021).

Cheek M, Cable S. 1997. Plant Inventory for conservation management: the Kew-Earthwatch programme in Western Cameroon, 1993-96, pp. 29-38 in Doolan, S. (Ed.) African Rainforests and the Conservation of Biodiversity, Oxford: Earthwatch Europe.

Cheek M, Onana JM. 2021. The endemic plant species of Mt Kupe, Cameroon with a new Critically Endangered cloud-forest tree species, Vepris zapfackii (Rutaceae). BioRxiv https://doi.org/10.1101/2021.06.01.446645 
Cheek M, Williams S. 1999. A Review of African Saprophytic Flowering Plants, pp. 39-49 in Timberlake \& Kativu (Eds.) African Plants. Biodiversity, Taxonomy \& Uses. Proceedings of the 15th AETFAT Congress at Harare, Zimbabwe. RBG, Kew.

Cheek M, Feika A, Lebbie A, Goyder D, Tchiengue B, Sene O, Tchouto P, Burgt X van der. 2017. A synoptic revision of Inversodicraea (Podostemaceae). Blumea 62:125-156.

https://doi.org/10.3767/blumea.2017.62.02.07

Cheek M, Gosline G, Onana JM. 2018a. Vepris bali (Rutaceae), a new critically endangered (possibly extinct) cloud forest tree species from Bali Ngemba, Cameroon. Willdenowia 48:285-292. https://doi.org/10.3372/wi.48.48207

Cheek M, Kami E, Kami T. 2014. Baphia vili sp. nov. (Leguminosae-Papilionoideae) of coastal thicket of the Congo Republic and Gabon. Willdenowia 44:39-44

http://dx.doi.org/10.3372/wi.44.44106

Cheek M, Mackinder B Gosline G, Onana J, Achoundong G. 2001. The phytogeography and flora of western Cameroon and the Cross River-Sanaga River interval. Systematics and Geography of Plants 71:1097-1100. https://doi.org/10.2307/3668742

Cheek M, Nic Lughadha E, Kirk P, Lindon H, Carretero J, Looney B,

Douglas B, Haelewaters D, Gaya E, Llewellyn T, Ainsworth M, Gafforov Y, Hyde K, Crous P, Hughes M, Walker BE, Forzza RC, Wong KM, Niskanen T. 2020. New scientific discoveries: plants and fungi. Plants, People Planet 2:371-388.

https://doi.org/10.1002/ppp3.10148

Cheek M, Oben B, Heller T. 2009. The identity of the West-Central African Oricia lecomteana Pierre, with a new combination in Vepris (Rutaceae). Kew Bull. 64:509-512

https://doi.org/10.1007/s12225-009-9135-1

Cheek M, Onana J-M, Yasuda S, Lawrence P, Ameka G, Buinovskaja G. 2019. Addressing the Vepris verdoorniana complex (Rutaceae) in West Africa, with two new species. Kew Bull. 74:53. https://doi.org/10.1007/S12225-019-9837-Y

Cheek M, Tchiengué B, van der Burgt X. 2021. Taxonomic revision of the threatened African genus Pseudohydrosme Engl. (Araceae), with $P$. ebo, a new, critically endangered species from Ebo, Cameroon. PeerJ 9:e10689 https://doi.org/10.7717/peerj.10689.

Cheek M, Tsukaya H, Rudall PJ, Suetsugu K. 2018b. Taxonomic monograph of Oxygyne (Thismiaceae), rare achlorophyllous mycoheterotrophs with strongly disjunct distribution. PeerJ 6: e4828. https://doi.org/10.7717/peerj.4828

Cheek M, van der Burgt X, Pickering H. 2010. Report of the vegetation and plant species survey at the MPD Port Site near Pointe Noire, Congo. Royal Botanic Gardens, Kew.

Cheplogoi PK, Mulholland DA, Coombes PH, Randrianarivelojosia M. 2008. An azole, an amide and a limonoid from Vepris uguenensis (Rutaceae). Phytochemistry 69:1384-1388.

https://doi.org/10.1016/j.phytochem.2007.12.013

Couch C, Cheek M, Haba PM, Molmou D, Williams J, Magassouba S, Doumbouya S, Diallo YM. 2019. Threatened Habitats and Important Plant Areas (TIPAs) of Guinea, West Africa. Kew: Royal Botanic Gardens. 
bioRxiv preprint doi: https//doi.org/10.1101/2021.08.22.457282; this version posted August 22, 2021. The copyright holder for this preprint (which was not certified by peer review) is the author/funder, who has granted bioRxiv a license to display the preprint in perpetuity. It is made available under aCC-BY-NC-ND 4.0 International license.

Dagallier LP, Janssens SB, Dauby G, Blach-Overgaard A, Mackinder BA, Droissart V, Svenning JC, Sosef MS, Stévart T, Harris DJ, Sonké B. 2020. Cradles and museums of generic plant diversity across tropical Africa. New Phytologist 225:2196-2213.

Damen TH, Van der Burg WJ, Wiland-Szymańska J, Sosef MSM. 2018. Taxonomic novelties in African Dracaena (Dracaenaceae). Blumea-Biodiversity, Evolution and Biogeography of Plants 63:31-53.

Darbyshire I, Anderson S, Asatryan A, Byfield A, Cheek M, Clubbe C, Ghrabi Z, Harris T, Heatubun CD, Kalema J, Magassouba S, McCarthy B, Milliken W, Montmollin B de, Nic Lughadha E, Onana JM, Saıdou D, Sarbu A, Shrestha K \& Radford, EA. 2017. Important Plant Areas: revised selection criteria for a global approach to plant conservation. Biodiversity Conservation 26:1767-1800. https://doi.org/10.1007/s10531-017-1336-6.

Dominy NJ, Duncan BW. 2005. Seed-spitting Primates and the Conservation and Dispersion of Large-seeded Trees. International Journal of Primatology 26:631-649.

https://doi.org/10.1007/s10764-005-4370-2

Engler A. 1931. Rutaceae. In: Engler A, Harms H (eds) Die Natürlichen Pflanzenfamilien Band 19a:187-359. Wilhelm Engelmann, Leipzig.

Gereau RE. 2001. New names in African Celastraceae and Rutaceae. Novon 11:43-44.

Gosline G, Cheek M, Kami T. 2014. Two new African species of Salacia (Salacioideae, Celastraceae). Blumea 59:26-32. https://doi.org/10.3767/000651914x682026

Haensel R, Cybulski EM. 1978. Alkaloids from the root bark of Vepris pilosa. Arch. Pharmazie. 311:135-138.

Harris DJ. 2000. Validation of the name Vepris glaberrima (Rutaceae). Kew Bulletin 55(2):458458.

Imbenzi PS, Osoro EK, Aboud NS, Ombito JO, Cheplogoi PK. 2014. A review on chemistry of some species of genus Vepris (Rutaceae family). Journal of Scientific and Innovative Research 3:357-362

IPNI. 2021. International Plant Names Index. The Royal Botanic Gardens, Kew, Harvard University Herbaria \& Libraries and Australian National Botanic Gardens. Available at http://www.ipni.org (accessed 05 July 2021).

IUCN. 2012. IUCN Red List Categories and Criteria: Version 3.1. Second edition. Gland, Switzerland and Cambridge, UK: IUCN. Available at http://www.iucnredlist.org/ (accessed: Aug. 2021).

Jane Goodall Institute. 2018. https://www.janegoodall.org/?portfolio=tchimpounga-safe-havensecond-chance-2-2 (accessed 8 Aug. 2021)

Kami T. 2021. Flore et Végétation en Relation avec l'Alimentation de Pan troglodytes a l'Est du Parc National Conkouati Douli. Thése Doctorale. Université Marien Ngouabi, Brazzaville.

Lachenaud O, Onana J-M. 2021. The West and Central African species of Vepris Comm. ex A.Juss. (Rutaceae) with simple or unifoliolate leaves, including two new combinations. Adansonia 43:107-116. 
bioRxiv preprint doi: https://doi.org/10.1101/2021.08.22.457282; this version posted August 22,2021 . The copyright holder for this preprint (which was not certified by peer review) is the author/funder, who has granted bioRxiv a license to display the preprint in perpetuity. It is made available under aCC-BY-NC-ND 4.0 International license.

Langat MK. 2011. Flindersiamine, a Furoquinoline Alkaloid from Vepris uguenensis (Rutaceae) as a Synergist to Pyrethrins for the Control of the Housefly, Musca domestica L. (Diptera: Muscidae). Journal of the Kenya Chemical Society. 6:9-15.

Langat MK, Mayowa Y, Sadgrove N, Danyaal M, Prescott TA, Kami T, Schwikkard S, Barker J, Cheek M. 2021. Multi-layered antimicrobial synergism of (E)-caryophyllene with minor compounds, tecleanatalensine B and normelicopine, from the leaves of Vepris gossweileri (I. Verd.) Mziray. Natural Product Research 1-11. https://doi.org/10.1080/14786419.2021.1899176

Letouzey R. 1963a. Rutaceae. Flore du Cameroun 1:1-121. Muséum national d'Histoire naturelle, Paris.

Letouzey R. 1963b. Rutaceae. Flore du Gabon 6:3-109. Muséum national d'Histoire naturelle, Paris.

Morton CM. 2017. Phylogenetic relationships of Vepris (Rutaceae) inferred from chloroplast, nuclear, and morphological data. PLOS ONE 12:

e0172708. https://doi.org/10.1371/journal.pone.0172708

Moxon-Holt L, Cheek M. 2020. Pseudohydrosme bogneri sp. nov. (Araceae), a spectacular Critically Endangered (Possibly Extinct) species from Gabon, long confused with Anchomanes nigritianus. BioRxiv https://doi.org/10.1101/2021.03.25.437040

Mziray W. 1992. Taxonomic studies in Toddalieae Hook.f. (Rutaceae) in Africa. Symb. Bot. Upsal. 30:1-95.

Nic Lughadha E, Govaerts R, Belyaeva I, Black N, Lindon H, Allkin, R, Magill RE, Nicolson N. 2016. Counting counts: Revised estimates of numbers of accepted species of flowering plants, seed plants, vascular plants and land plants with a review of other recent estimates. Phytotaxa 272:82-88. https://doi.org/10.11646/phytotaxa.272.1.5

Okoye NN, Ajaghaku DL, Okeke HN, Ilodigwe EE, Nworu CS, Okoye FBC. 2014. betaAmyrin and alpha-amyrin acetate isolated from the stem bark of Alstonia boonei display profound anti-inflammatory activity. Pharmaceutical Biology 52:11, 1478-1486, DOI:

$10.3109 / 13880209.2014 .898078$

Ombito JO, Chi GF, Wansi JD. 2020. Ethnomedicinal uses, phytochemistry, and pharmacology of the genus Vepris (Rutaceae): A review. Journal of Ethnopharmacology, 267:113622.

https://doi.org/10.1016/j.jep.2020.113622

Onana J-M, Cheek M. 2011. Red Data Book of the flowering plants of Cameroon, IUCN global assessments. Kew: Royal Botanic Gardens.

Onana J-M, Chevillotte H. 2015. Taxonomie des Rutaceae-Toddalieae du Cameroun revisitée: découverte de quatre espèces nouvelles, validation d'une combinaison nouvelle et véritable identité de deux autres espèces de Vepris Comm. ex A. Juss. Adansonia, sér. 3. 37:103-129.

https://doi.org/c10.5252/a2015n1a7

Onana J-M, Cheek M, Chevillotte H. 2019. Additions au genre Vepris Comm. ex A. Juss. (Rutaceae-Toddalieae) au Cameroun. Adansonia 41:41-52.

https://doi.org/10.5252/adansonia2019v41a5 
bioRxiv preprint doi: https://doi org/10.1101/2021.08.22.457282; this version posted August 22 2021. The copyright holder for this preprint (which was not certified by peer review) is the author/funder, who has granted bioRxiv a license to display the preprint in perpetuity. It is made available under aCC-BY-NC-ND 4.0 International license.

POWO. Continuously updated. Plants of the World Online. Facilitated by the Royal Botanic Gardens, Kew. Published on the Internet; http://www.plantsoftheworldonline.org/

(downloaded 1 May 2021)

Pusset J, Lopez JL, Pais M, Al-Neirabeyeh M, Veillon JM. 1991. Isolation and 2D NMR studies of alkaloids from Comptonella sessifoliola. Planta Medica 57:153-155.

Sengupta A, McConkey KR, Radhakrishna S. 2015. Primates, Provisioning and Plants: Impacts of Human Cultural Behaviours on Primate Ecological Functions. PLoS ONE 10(11): e0140961. https://doi.org/10.1371/journal.pone.014096

Shorthouse DP. 2010. SimpleMappr, an online tool to produce publication-quality point maps. [Retrieved from http://www.simplemappr.net accessed 28 May 2021]

Soltis DE, Clayton JW, Davis CC, Wurdack KJ, Gitzendanner MA, Cheek M, Savolainen V, Amorim AM, Soltis PS. 2007. Monophyly and relationships of the enigmatic family Peridiscaceae. Taxon 56:65-73.

Sosef MSM, Wieringa JJ, Jongkind CCH, Achoundong G, Azizet Issembé Y, Bedigian D, Van Den Berg RG, Breteler FJ, Cheek M, Degreef J. 2005. Checklist of Gabonese Vascular Plants. Scripta Botanica Belgica 35. National Botanic Garden of Belgium.

Thiers B. continuously updated. Index Herbariorum: A global directory of public herbaria and associated staff. New York Botanical Garden's Virtual Herbarium. Available at http://sweetgum.nybg.org/ih/ (accessed June 2020).

Turland NJ, Wiersema JH, Barrie FR, Greuter W, Hawksworth DL, Herendeen PS, Knapp S, Kusber W-H, Li D-Z, Marhold K, May TW, McNeill J, Monro AM, Prado J. Price MJ, Smith GF. (ed.) 2018. International Code of Nomenclature for algae, fungi, and plants (Shenzhen Code) adopted by the Nineteenth International Botanical Congress Shenzhen, China, July 2017.Glashütten: Koeltz Botanical Books. [= Regnum Veg. 159].

Van der Burgt X, Merklinger F. 2012. Preliminary report of a Vegetation and Plant Species Survey at the MPD Port Site near Pointe Noire, Congo (Brazzaville).

Vande Weghe JP. 2007. Loango, Mayumba et le bas Ogooue. Wildlife Conservation Society, Libreville, Gabon (ISBN 978-0-9792418-1-9)

Vaquette J, Hifnawy MS, Pousset A, Fournet A, Bouquet A, Cave A. 1976. Alcaloides d'Araliopsis soyauxii. Isolement d'un nouvel alcaloide, l'araliopsine. Phytochemistry 15:743-745

Verdoorn IC. 1926. Revision of African Toddalieae. Bulletin of Miscellaneous Information, Royal Botanic Gardens, Kew 9:389-416. https://www.jstor.org/stable/4118639

Wansi JD, Mesaik M, Chiozem DD, Devkota KP, Gaboriaud-Kolar N, Lallemand M-C, Wandji J, Choudhary MI, Sewald N. 2008. Oxidative Burst Inhibitory and Cytotoxic Indoloquinazoline and Furoquinoline Alkaloids from Oricia suaveolens. Journal of Natural Products 71:1942-1945. https://doi.org/10.1021/np800276f

World Conservation Monitoring Centre. 1998. Vepris trifoliolata. The IUCN Red List of Threatened Species 1998: e.T46175A11033334.

https://dx.doi.org/10.2305/IUCN.UK.1998.RLTS.T46175A11033334.en 